\title{
Wat werkt in een integrale aanpak van overgewicht voor mensen met een lage sociaaleconomische status en/of een niet westerse migratieachtergrond?
}

\author{
Vicky Dellas · Dorine Collard · Caro-Lynn Verbaan · Erik Beune · Annemarie Wagemakers
}

Geaccepteerd op: 6 september 2021 / Published online: 14 oktober 2021

(C) The Author(s) 2021

\begin{abstract}
Samenvatting Het percentage mensen met ernstig overgewicht neemt de komende jaren toe, vooral onder mensen met een kwetsbare positie, zoals groeperingen met een lage sociaaleconomische status (SES) en/of een niet-westerse migratieachtergrond. Overgewicht is een complex probleem dat vraagt om een integrale aanpak. Het doel van dit onderzoek is het voor deze doelgroepen identificeren van potentieel werkzame elementen van een integrale aanpak gericht op overgewicht. In dit exploratief kwalitatieve onderzoek zijn twaalf groepsinterviews met 25 professionals en vier focusgroepgesprekken met 24 mensen uit de doelgroep gehouden. In totaal zijn 41 potentieel werkzame elementen geïdentificeerd voor een succesvolle integrale aanpak. Deze zijn ingedeeld op het individuele, programma, gemeentelijk en landelijk niveau, en op de sociale en fysieke omgeving. Hiervan hebben achttien potentieel werkzame elementen specifiek betrekking op mensen met een lage SES en/of niet-westerse migratieachtergrond. Daarnaast zijn vier competenties van professionals geïdentificeerd die in potentie kunnen bijdrage aan een werkzame integrale aanpak: verbinden, durven, integraal werken, volhouden. De
\end{abstract}

Digitaal aanvullende content De online versie van dit artikel (https://doi.org/10.1007/s12508-021-00315-w) bevat aanvullend materiaal, toegankelijk voor daartoe geautoriseerde gebruikers.

V. Dellas · D. Collard (殴

Mulier Instituut, Utrecht, Nederland

d.collard@mulierinstituut.nl

C. Verbaan · A. Wagemakers

Health \& Society, Social Sciences Group, Wageningen

University \& Research, Wageningen, Nederland

\section{E. Beune}

Amsterdam Public Health Research Institute, Afdeling Public and Occupational Health, Amsterdam UMC, Universiteit van Amsterdam, Amsterdam, Nederland twee randvoorwaarden tijd en financiële middelen lijken relevant op alle niveaus. Dit exploratieve onderzoek laat zien dat een integrale aanpak van professionals niet alleen vraagt dat zij verschillende potentieel werkzame elementen (tegelijkertijd) inzetten, maar ook dat ze zich continu en proactief inspannen om dit te realiseren.

Trefwoorden werkzame elementen · integrale aanpak · leefstijlinterventie · overgewicht · lage SES . niet-westerse migratieachtergrond

\section{What works in an integrated approach obesity for people with a low socio-economic position and/or a non-Western migration background?}

Abstract In coming years, the percentage of people who are overweight will increase most among vulnerable people, such as people with a low socio-economic status (SES) and/or a non-Western migration background. Overweight is a complex problem that requires an integrated approach. The aim of this research is to determine potentially effective elements of an integrated approach aimed at overweight for these specific target groups. In this explorative qualitative research twelve group interviews with professionals $(n=25)$ and four group interviews $(n=24)$ with people from the target group were conducted. In total 41 potentially effective elements have been identified for a successful integrated approach. These elements can be classified at the individual, program, municipal and national level, and the social and physical environment. Of these, 18 potentially effective elements relate specifically to people with a low SES and/or non-Western migration background. In addition, there are four competencies regarding the professional that can potentially contribute to an integrated approach: connect, dare, work in an integrated 
manner, persevere. The two preconditions of time and financial resources seem relevant. This study shows that an integrated approach not only requires professionals to deploy various effective elements (simultaneously), but also a continuous and proactive effort to achieve this.

Keywords Effective elements · Lifestyle intervention · Integrated approach · Overweight · Low socioeconomic status · Migrants

\section{Inleiding}

In 2019 had 35\% van de Nederlanders van achttien jaar en ouder overgewicht $(25 \geq \mathrm{BMI}<30)$, en had $15 \%$ obesitas $(30 \geq \mathrm{BMI})$ [1]. Overgewicht komt vaker voor bij mensen met een lage sociaaleconomische status (SES) en/of een niet-westerse migratieachtergrond [1]. Deze doelgroepen hebben ook relatief vaker een ongezonde leefstijl, eten minder groente en fruit, en bewegen minder [2]. Hoewel het percentage mensen met overgewicht de afgelopen jaren in alle sociaaleconomische lagen is gestegen, zien we een grotere stijging onder mensen met een lage SES. Hierdoor worden gezondheidsverschillen groter [3].

Tot nu toe is het lastig gebleken om een gezonde leefstijl en gezond gewicht te stimuleren bij mensen met een lage SES en/of niet-westerse migratieachtergrond. Specifieke aandacht voor deze groepen is nodig omdat zij met het huidige aanbod niet of onvoldoende worden bereikt [4]. In het Nationaal Preventieakkoord is het voorkomen en verminderen van overgewicht een belangrijke speerpunt [5]. Een van de acties is het inzetten van (gecombineerde) leefstijlinterventies (GLI's) [6, 7]. Een groot deel van de interventies, zoals opgenomen in de Databank Erkende Interventies van het Loket Gezond Leven [8], is echter niet specifiek voor deze doelgroepen ontwikkeld [9, 10].

Hoewel GLI's bijdragen aan het verminderen van overgewicht, richten deze zich op het realiseren van gedragsverandering bij de deelnemers. Omdat overgewicht wordt gezien als complex probleem, waarbij ook andere contextuele factoren een rol spelen, wordt een bredere integrale aanpak aanbevolen [5, 11]. Zo'n aanpak betekent dat er wordt samengewerkt tussen verschillende beleidsdomeinen (gezondheid, welzijn, sport, leefbaarheid, sociale zaken), tussen meerdere partijen (gemeente, sport- en beweegsector, zorgsector, welzijnssector) en in diverse settings (school, wijk, werk). Binnen een integrale aanpak kunnen verschillende acties worden genomen, zoals het creëren van een beweegvriendelijke omgeving of betaalbare woningen.

Werkzame elementen zijn de onmisbare onderdelen die ervoor zorgen dat een aanpak de gewenste effecten heeft [12]. Het identificeren van de werkzame elementen draagt bij aan het verbeteren van de toepasbaarheid in de praktijk en het vergroten van de effectiviteit [12]. Tot op heden is vooral onderzoek gedaan naar werkzame elementen van GLI's voor de algemene bevolking en in mindere mate voor mensen met een lage SES [13-16]. De werkzame elementen die in de onderzoeken van Mulderij en collega's zijn gevonden, hingen vooral samen met het programma, bijvoorbeeld de samenwerking van de professionals, wervingsstrategieën, afspraken met deelnemers en aansluiten bij de doelgroep [15, 16]. Er is weinig onderzoek gedaan naar de werkzame elementen van een brede integrale aanpak die specifiek gericht is op mensen met een lage SES. Ook in een recente scoping review naar de aanpak van overgewicht bij kwetsbare doelgroepen werden voornamelijk werkzame elementen gevonden die gerelateerd zijn aan een interventie en niet aan een integrale aanpak [17].

Daarom is het doel van dit verkennende onderzoek het identificeren van de potentieel werkzame elementen van een integrale aanpak gericht op overgewicht voor mensen met een lage SES en/of een niet-westerse migratieachtergrond, vanuit het perspectief van professionals en de doelgroep. Professionals hebben inzicht in het toepassen van werkzame elementen in de praktijk en de doelgroep kan het beste zelf aangeven wat voor hen werkt. Inzicht in werkzame elementen draagt bij aan het verbeteren van een integrale aanpak voor deze doelgroepen, en uiteindelijk aan het vergroten van het gezondheidspotentieel voor degene met de grootste gezondheidsachterstand.

Dit onderzoek maakt deel uit van het Programma Effectiviteitsonderzoek, subsidieronde Werkzame Elementen Fase 1 met projectnummer 5555002011, en is gefinancierd door ZonMw.

\section{Methode}

Om potentieel werkzame elementen inzichtelijk te maken is exploratief kwalitatief onderzoek uitgevoerd in de vorm van (groeps)interviews met professionals en focusgroepgesprekken met de doelgroep om de dialoog onderling en met de onderzoekers te stimuleren [18]. De (groeps)interviews werden geleid door VD en een van de andere onderzoekers (CV, DC, EB of AW) en de focusgroepgesprekken zijn uitgevoerd onder leiding van VD en CV.

\section{(Groeps)interviews met de professionals}

In totaal namen 25 professionals deel uit de praktijk $(n=7)$, het beleidsdomein $(n=5)$ en de wetenschap $(n=13)$ met expertise op het gebied van sport en bewegen, voeding en/of een gezonde leefstijl (tab. 1). Professionals uit de praktijk waren bijvoorbeeld leefstijlcoaches of diëtisten die werkten met de doelgroep. Beleidsprofessionals voerden landelijk of gemeentelijk gezondheidsbeleid uit en onderzoekers waren deskundig in het evalueren van leefstijlprogramma's. Alle respondenten spraken vanuit concrete ervaring met integrale benaderingen voor de doelgroep. 
Tabel 1 Aantal deelnemende professionals per interviewsessie en de organisatie(s) waar zij werkzaam waren

\begin{tabular}{|c|c|c|}
\hline & $\begin{array}{l}\text { aantal deelnemende } \\
\text { professionals }\end{array}$ & $\begin{array}{l}\text { organisatie(s) waar de professionals werk- } \\
\text { zaam zijn }\end{array}$ \\
\hline 1 & 2 & Kenniscentrum Sport en Bewegen \\
\hline 2 & 2 & RIVM \\
\hline 3 & 1 & Vereniging van Sport en Gemeenten \\
\hline 4 & 2 & NL Actief \\
\hline 5 & 2 & GGD \\
\hline 6 & 2 & GGD, Sportbedrijf \\
\hline 7 & 3 & $\begin{array}{l}\text { Investeringsfonds, gezondheidscentrum, } \\
\text { gezondheidsinnovaties }\end{array}$ \\
\hline 8 & 3 & Universiteit Wageningen \\
\hline 9 & 3 & Amsterdam AMC, diëtistenpraktijk \\
\hline 10 & 2 & $\begin{array}{l}\text { GGD, Gemeente Nijmegen, Radboud Uni- } \\
\text { versiteit }\end{array}$ \\
\hline 11 & 1 & Sportschool \\
\hline 12 & 2 & $\begin{array}{l}\text { Ministerie van Volksgezondheid Welzijn en } \\
\text { Sport }\end{array}$ \\
\hline Totaal & 25 & \\
\hline
\end{tabular}

Werving vond plaats per mail of telefonisch via het netwerk van de onderzoeksgroep en via de sneeuwbalmethode. In totaal zijn 31 professionals benaderd, van wie zes niet deelnamen vanwege gebrek aan tijd of belangstelling.

De (groeps)interviews met professionals gingen over de werkzame elementen van een integrale aanpak. De vragen in de (groeps)interviews waren gebaseerd op de principes van waarderend interviewen, waarbij de focus ligt op een positieve benadering om gezamenlijke nieuwe kennis te verkrijgen [19]. Aan de respondenten is gevraagd wat hun ervaringen en successen zijn met een integrale aanpak, en vervolgens hoe de 'ideale integrale aanpak' van overgewicht voor mensen met een lage SES en/of een niet-westerse migratieachtergrond eruitziet en wat nodig is om deze uit te voeren. De focus lag daarbij op de werkzame elementen. Aan professionals is gevraagd op papier de ideale aanpak te schetsen en deze toe te lichten. Door professionals te laten tekenen kan een diepgaander inzicht verkregen worden in de complexiteit en de verschillende factoren van het vraagstuk [20, 21]. De (groeps)interviews duurden gemiddeld $75 \mathrm{mi}$ nuten (40-90 minuten) en vonden plaats in het najaar van 2019 bij de organisatie van de professional(s).

\section{Focusgroepgesprekken met de eindgebruikers}

Er zijn vier focusgroepgesprekken gehouden met in totaal 24 deelnemers (17 vrouwen) van drie verschillende leefstijlinterventies (X-Fittt 2.0 (tweemaal), CooL en Bollywood Dance). Deze deelnemers, voornamelijk mensen met een lage SES en/of niet-westerse migratieachtergrond $(n=11)$, zijn groepsgewijs geworven via de trainers van de programma's. De respondenten participeerden al geruime tijd in een van de leefstijlinterventies en konden daarom van- uit hun ervaring kennis delen. In de focusgroepen ging het vooral over de werkzame elementen van het programma waaraan de respondenten deelnamen, omdat ze geen inzicht of ervaring hadden met een brede integrale aanpak. Er is gebruikgemaakt van een semigestructureerde leidraad gebaseerd op de APEF (Active Participation, Enjoyment, and Fostering group processes)-methode. APEF is een cultureel sensitieve methode die geschikt is voor het stimuleren van een dialoog in groepen door middel van stellingen [22]. De stellingen zijn geformuleerd en aangepast op basis van eerder onderzoek onder lage SES-groepen [23, 24]. 'Doordat ik sport in een groep, vind ik het leuk om te bewegen' en 'De trainer motiveert en stimuleert mij om te bewegen' zijn voorbeelden van stellingen op basis waarvan met de doelgroep gesproken is over hun ervaringen met het programma waar ze aan deelnamen. De focusgroepgesprekken duurden ongeveer een uur en vonden plaats in het najaar van 2019 op de locatie waar de leefstijlinterventie werd uitgevoerd. De deelnemers van de focusgroepen kregen een cadeaubon ter waarde van 7,50 euro.

\section{Analyse van de groepsinterviews en focusgroepgesprekken}

De (groeps)interviews en focusgroepgesprekken zijn met behulp van het softwareprogramma MaxQda getranscribeerd (ad verbatim) en onafhankelijk gecodeerd door $\mathrm{VD}$ en een tweede onderzoeker $(\mathrm{CV}$, DC, EB of AW). Bij de analyse zijn de codes uit een eerder onderzoek naar werkzame elementen gebruikt als startpunt voor een deductieve analyse [15]. Vervolgens zijn inductief codes aangevuld op basis van de data uit de (groeps)interviews, focusgroepgesprekken en tekeningen van de professionals. Dit heeft geleid tot hoofdcodes en subcodes die op verschillende niveaus zijn gecategoriseerd. Alle tekeningen zijn samengevoegd tot één complete tekening, met de indeling naar niveaus en codes (fig. 1). De codes en het samenvoegen en indelen ervan zijn net zolang besproken door de auteurs tot consensus was bereikt. Er bleken ook werkzame elementen benoemd die niet specifiek voor de doelgroep golden. Daarom zijn de werkzame elementen geselecteerd waarvan de professionals specifiek aangegeven hadden dat deze in hoge mate relevant zijn voor mensen met een lage SES en/of niet-westerse migratieachtergrond. De resultaten zijn teruggekoppeld en geverifieerd in een expertmeeting met 26 professionals uit achttien verschillende organisaties vanuit beleid, praktijk en onderzoek.

\section{Resultaten}

Er zijn 41 potentieel werkzame elementen en passende acties van een integrale aanpak overgewicht geïdentificeerd (Bijlage 1, zie digitaal aanvullende content). Dit zijn de elementen die het meest ge- 


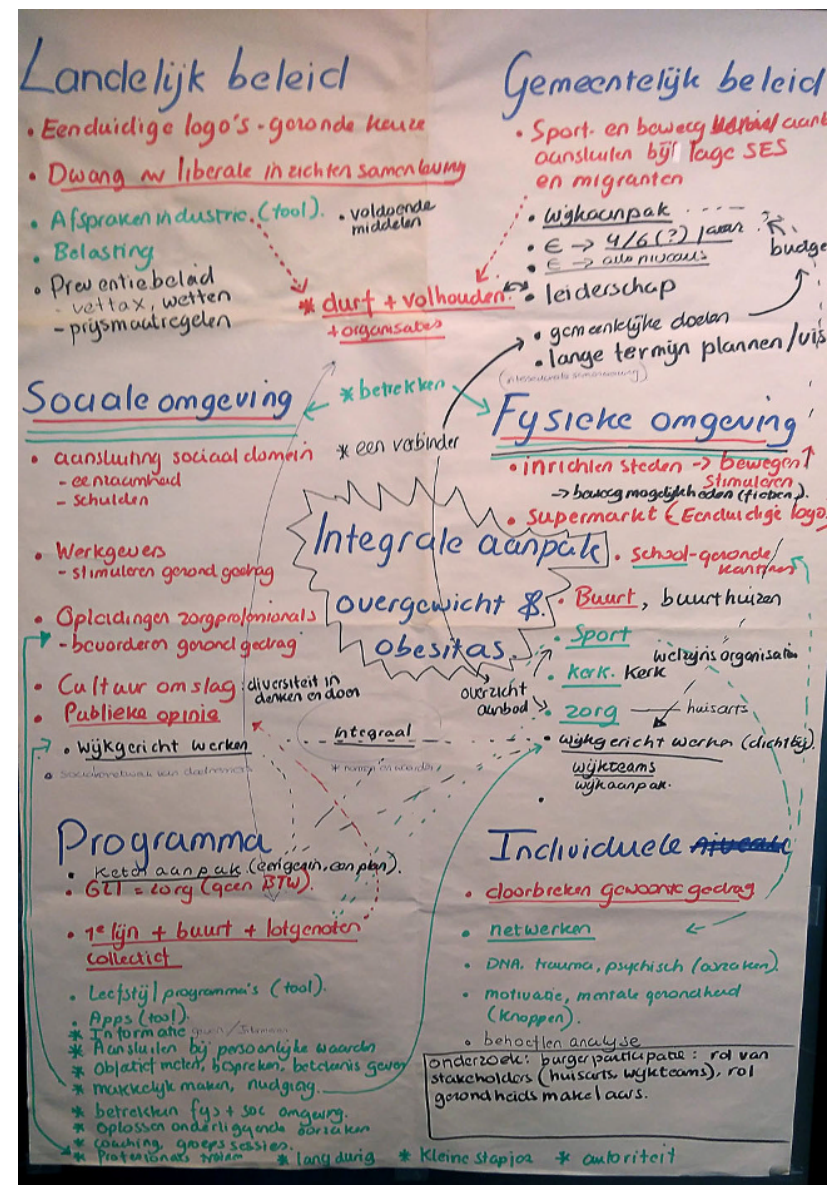

Figuur 1 De complete tekening, met de indeling naar niveaus en codes

noemd zijn door meerdere professionals. De werkzame elementen zijn gecategoriseerd in zes niveaus: het individuele $(n=4)$, programma- $(n=22)$, gemeentelijk $(n=4)$ en landelijk niveau $(n=4)$, de sociale $(n=4)$ en fysieke omgeving $(n=3)$. Van de 41 genoemde werkzame elementen waren er achttien waarvan professionals specifiek hebben aangegeven dat deze voor de doelgroep relevant zijn (tab. 2).

Naast de potentieel werkzame elementen zijn ook vier competenties van professionals benoemd die lijken te kunnen bijdragen aan een werkzame integrale aanpak, te weten verbinden (van beleidsterreinen en partners), durven (te vertrouwen), integraal werken (partners hebben een gezamenlijk doel) en volhouden. Daarnaast zijn twee belangrijke randvoorwaarden benoemd die relevant lijken op alle niveaus, namelijk tijd en geld.

\section{Individueel niveau}

Professionals vinden het vergroten van de persoonlijke kennis van de einddoelgroep belangrijk. Werkzame elementen daarbij kunnen zijn het vergroten van de kennis over rechten op financiële hulpmiddelen, zoals het bestaan van gemeentelijke fondsen, en kennis gerelateerd aan de risico's van overgewicht en/of een ongezonde leefstijl. Volgens de professionals kunnen gemeentelijke fondsen bijdragen aan het toegankelijker maken van het reguliere sport- en beweegaanbod, en kan kennis over de risico's van overgewicht deelnemers motiveren tot een gezonde(re) leefstijl.

\begin{abstract}
Ik denk ook dat heel veel mensen niet beseffen dat er heel veel ziektelast is [...] De kwaliteit van leven gaat heel hard omlaag, weet je wel. Ik weet niet of we dat verhaal wel genoeg vertellen. (Interview 12)
\end{abstract}

\section{Programmaniveau}

De meeste potentieel werkzame elementen werden op het programmaniveau genoemd. Deze zijn ingedeeld in zes thema's. Het eerste thema, aandacht voor- en aansluiten bij het dagelijks leven van de doelgroep, betekent bijvoorbeeld dat schuldhulpverlening onderdeel moet zijn van een integrale aanpak. Professionals lichtten toe dat financiële problemen tot stress leiden, waardoor er weinig ruimte is voor een gezondere leefstijl.

Je kan wel bij leefstijl beginnen, maar als mensen met schulden zitten, dan bepaalt dat gewoon [...]. Ja, dan slaap je niet goed, dan eet je vaak niet zo goed. Dat telt op. [...]. Schulden zijn een wezenlijke zorg. [...] Je zou kunnen zeggen dat het voorliggend is op het overgewicht. [...] daar ligt iemand meer wakker van dan dat-ie te dik is. (Interview 12)

Zowel professionals als mensen uit de doelgroep noemen het rekening houden met de cultuur, het begeleiden van deelnemers naar het reguliere sport- en beweegaanbod, materialen die aansluiten bij de geletterdheid van de doelgroep en lage deelnemerskosten als werkzame elementen. Voor deelnemers met een lage SES en/of niet-westerse migratieachtergrond is de overgang van een programma naar het reguliere sport- en beweegaanbod vaak een grote stap. Ze weten bijvoorbeeld niet waar ze na afloop van een programma terecht kunnen en wat de kosten zijn.

In de focusgroepgesprekken kwam het belang van het rekening houden met de cultuur en geletterdheid van de doelgroep herhaaldelijk naar voren.

Ik had de app van [naam docent] gekregen. Maar $i k$ heb het geprobeerd, ik zeg tegen [vriend]: ik snap er helemaal niks van hoe dat ding werkt. (Focusgroep 3)

Ook benadrukten de deelnemers dat de programma's aantrekkelijker zijn om voor op te geven als de kosten ervan laag zijn.

$J a$, en het is heel erg goedkoop, het is $€ 2,50$ en je krijgt les. En als je een keer niet kan komen, dan hoef je ook niet te betalen. (Focusgroep 4) 
Tabel 2 Overzicht van de geïdentificeerde potentieel werkzame elementen specifiek voor mensen met een lage SES en/of niet-westerse migratieachtergrond en de daarbij behorende acties

\begin{tabular}{|l|l|}
\hline $\begin{array}{l}\text { niveau (thema) } \\
\text { individueel } \\
\text { (persoonlijke kennis) }\end{array}$ & $\begin{array}{l}\text { Het individu is op de hoogte van de } \\
\text { rechten die zij/hij heeft. }\end{array}$ \\
$\qquad \begin{array}{l}\text { Het individu is op de hoogte van de } \\
\text { gezondheidsgevaren als gevolg van een } \\
\text { ongezonde leefstijl en/of overgewicht. }\end{array}$ \\
$\qquad \begin{array}{l}\text { Het individu is op de hoogte van de } \\
\text { gezondheidsgevaren als gevolg van een } \\
\text { ongezonde leefstijl en/of overgewicht. }\end{array}$ \\
\hline
\end{tabular}
samenvatting - actie

programma (aandacht voor de dagelijkse zorgen en barrières van (individuen binnen) de doelgroep)

programma (aandacht voor sociale context

\section{programma} (aansluiten op het dagelijkse leven en bestaande structuren van de doelgroep en de gemeenschap)

\section{programma}

(inzetten van bekende gezichten en professionals met dezelfde culturele achtergrond)

programma (competente en enthousiaste professionals)

programma (continuïteit)

Schuldhulpverlening is onderdeel van het programma.

Binnen het programma wordt rekening gehouden met culturele barrières van de

Deelnemers worden begeleid naar het reguliere sport- en beweegaanbod.

De materialen sluiten aan bij de geletterdheid van de doelgroep. ${ }^{\mathrm{a}}$

De kosten die aan het programma zijn

Het programma richt zich op het hele gezin of de wijk, in plaats van alleen op een individuele deelnemer.

Het bereiken en werven van de doelgroep gaat via moskeeën, buurtcentra, de lokale markt en andere plekken waar de doelgroep zich bevindt en vertrouwd voelt.

De activiteiten van het programma vinden plaats op een voor de (potentiële) deelnemers bekende locatie dichtbij huis. $^{\mathrm{a}}$

Bekende gezichten en sleutelfiguren uit de gemeenschap worden ingezet voor het bereiken en werven van de doelgroep.

Professionals met dezelfde culturele achtergrond worden ingezet bij de ontwikkeling en implementatie van het programma. $^{\text {a }}$

Professionals hebben respect voor de doelgroep en stigmatiseren niet. (professionals ken- sociale kaart en kennen personen die nen elkaar en weten daarbinnen actief zijn.

elkaar te vinden)

Programma's zijn geborgd en lopen continu door, zodat mensen kunnen inen uitstromen wanneer ze dat willen. doelgroep. ${ }^{\text {a }}$ verbonden zijn laag. ${ }^{\text {a }}$

Mensen met een lage SES en/of migratieachtergrond maken niet altijd gebruik van hun rechten op financiële hulpmiddelen, omdat ze hiervan niet op de hoogte zijn.

- Informeer mensen met een lage SES en/of migratieachtergrond over de rechten en mogelijkheden die ze hebben wat betreft (gemeentelijke) fondsen.

Mensen met een lage SES en/of migratieachtergrond zijn niet altijd op de hoogte van de gevolgen van overgewicht en/of een gezonde leefstijl. Hierdoor zijn ze minder gemotiveerd om af te vallen of een gezonde leefstijl na te streven.

- Informeer mensen over de gezondheidsgevaren van overgewicht en/of een ongezonde leefstijl. Mensen met een lage SES en/of migratieachtergrond zijn niet altijd op de hoogte van de gevolgen van overgewicht en/of een gezonde leefstijl. Hierdoor zijn ze minder gemotiveerd om af te vallen of een gezonde leefstijl na te streven.

- Informeer mensen over de gezondheidsgevaren van overgewicht en/of een ongezonde leefstijl. Mensen met een lage SES en/of migratieachtergrond ervaren vaak stress door financiële problemen. Een gezonde leefstijl ontwikkelen heeft daardoor niet altijd prioriteit.

- Neem schuldhulpverlening op als onderdeel van het programma.

Vooral mensen met een migratieachtergrond kunnen bepaalde culturele barrières ervaren.

- Zet programma's op die cultureel sensitief zijn.

Voor mensen met een lage SES en/of migratieachtergrond kan doorstromen naar het reguliere sport- en beweeg aanbod een probleem vormen.

- Begeleid deelnemers naar het reguliere sport- en beweegaanbod en zorg voor een warme overdracht.

Mensen met een lage SES en vooral degenen met een migratieachtergrond kunnen moeite hebben met het lezen en begrijpen van de Nederlandse taal.

- Gebruik simpele materialen met makkelijke taal en beelden.

Deelname aan programma's en/of sport- en beweegactiviteiten is al snel te duur voor mensen met een lage SES en/of migratieachtergrond.

- Zet programma's op waarvan de kosten voor de deelnemers kosten laag zijn.

De sociale omgeving van individuen speelt een belangrijke rol in het hebben van een gezonde leefstijl. Mensen met een lage SES en/of migratieachtergrond leven over het algemeen in een gezin en/of wijk die ongezond(er) is dan mensen uit een andere doelgroep.

- Zet programma's op waarbij het hele gezin of de wijk wordt betrokken.

Mensen met een lage SES en vooral degenen met een migratieachtergrond stellen zich makkelijker open in een dagelijkse en vertrouwde omgeving.

- Bereik en werf de doelgroep door naar hen toe te bewegen.

Wanneer activiteiten op een voor de doelgroep toegankelijke plek plaatsvinden wordt het makkelijker voor hen om te komen en ook het programma langer vol te houden.

- Bied activiteiten aan op locaties die voor de doelgroep dichtbij huis en bekend zijn.

Vooral mensen met een migratieachtergrond kunnen terughoudend zijn wanneer ze worden aangesproken door een onbekende persoon met een andere culturele achtergrond.

- Zet iemand van de gemeenschap die de mensen vertrouwen in voor het bereiken en werven, bijvoorbeeld een imam of andere sleutelfiguur.

Zowel gedurende de ontwikkelings- als tijdens de implementatiefase is het belangrijk om de culturele sensitiviteit en tegelijkertijd ook de kundigheid binnen het programma te waarborgen. - Zet professional met dezelfde culturele achtergrond als de doelgroep in.

Mensen met een lage SES en/of migratieachtergrond zijn kwetsbaar. Een vertrouwensband draagt bij aan het bespreekbaar maken van onderliggende problematiek, wat weer ruimte geeft om te werken aan een gezonde leefstijl.

- Een competente professional stigmatiseert en labelt de doelgroep niet.

Veel programma's die worden opgezet zijn na het stoppen van bijvoorbeeld een subsidie afgelopen. Deelnemers moeten dan iets nieuws zoeken, wat voor mensen met een lage SES en/of migratieachtergrond vaak een probleem vormt

- Denk na over en zorg voor een goede borging van de programma's die worden opgezet.

Mensen met een lage SES en/of migratieachtergrond hebben te maken met verschillende soorten problematiek en zijn ook makkelijk 'kwijt te raken' binnen een traject. Het is van belang dat professionals hen snel kunnen doorverwijzen en verbinden aan de juiste hulpverlener of organisatie.

- Professionals weten waar de juiste hulp zich bevindt (kennen de sociale kaart) en hebben korte lijntjes met de juiste mensen. 
Tabel 2 (Vervolg)

\begin{tabular}{|c|c|c|}
\hline niveau (thema) & werkzaam element & samenvatting - actie \\
\hline $\begin{array}{l}\text { gemeentelijk } \\
\text { (samenwerking met } \\
\text { relevante stakehol- } \\
\text { ders) }\end{array}$ & $\begin{array}{l}\text { Publieke en private organisaties worden } \\
\text { betrokken bij het realiseren en financie- } \\
\text { ren van onderdelen binnen de integrale } \\
\text { aanpak. }\end{array}$ & $\begin{array}{l}\text { Sommige organisaties staan dichtbij (de problematiek van) mensen met een lage SES en/of } \\
\text { migratieachtergrond. } \\
\text { - Betrek relevante stakeholders erbij wanneer die een belangrijke rol kunnen spelen bij de } \\
\text { aanpak. }\end{array}$ \\
\hline $\begin{array}{l}\text { landelijk } \\
\text { (financiële middelen } \\
\text { voor de doelgroep) }\end{array}$ & $\begin{array}{l}\text { De overheid stelt financiële middelen } \\
\text { beschikbaar om het naleven van een } \\
\text { gezonde leefstijl betaalbaar te maken } \\
\text { voor degenen die het nodig hebben. }\end{array}$ & $\begin{array}{l}\text { Een gezonde leefstijl lijkt door van financiële problemen en dure gezonde producten/goedkope } \\
\text { ongezonde producten soms moeilijk te handhaven door mensen met een lage SES en/of migratie- } \\
\text { achtergrond. } \\
\text { - De overheid treft een regeling om een gezonde leefstijl en het aanpakken van overgewicht } \\
\text { betaalbaar te maken. }\end{array}$ \\
\hline $\begin{array}{l}\text { sociale omgeving } \\
\text { (vertrouwens- } \\
\text { persoon) }\end{array}$ & $\begin{array}{l}\text { Aan een individu is een vertrouwensper- } \\
\text { soon verbonden die hem/haar binnen de } \\
\text { aanpak begeleid en waarop hij/zij terug } \\
\text { kan vallen. }\end{array}$ & $\begin{array}{l}\text { Mensen met een lage SES en/of migratieachtergrond hebben soms extra begeleiding nodig bij } \\
\text { het werken aan een gezonde leefstijl en deze ook vol te houden. Deze extra begeleiding kan } \\
\text { gedaan worden vanuit een professional of iemand uit de persoonlijke omgeving. Belangrijk is dat } \\
\text { deze persoon wordt vertrouwd. } \\
\text { - Zorg ervoor dat elk individu verbonden is aan een persoon die hij/zij vertrouwt en hem/haar } \\
\text { begeleidt. }\end{array}$ \\
\hline
\end{tabular}

Werkzame elementen bij de thema's 'aandacht voor de sociale context', 'aansluiten bij het dagelijks leven van de doelgroep' en 'inzetten van bekende gezichten en sleutelfiguren' hangen met elkaar samen. Professionals zien dat een gezins- of een wijkaanpak beter werkt dan een aanpak alleen gericht op het individu.

Het is belachelijk dat als iemand bij een huisarts komt en die te dik is, dat de huisarts alleen maar met zo iemand wat gaat doen. Eigenlijk moet hij het hele gezin of belangrijke mensen in de omgeving van die persoon. Dat wordt niet gedaan. (Interview 10).

Een ander genoemd werkzaam element is het werven van mensen in een vertrouwde omgeving, dichtbij huis, en via een vertrouwd iemand uit de sociale omgeving. De doelgroep stelt zich gemakkelijker open in een voor hen vertrouwde omgeving, zoals buurtcentra, moskeeën en de lokale markt.

Het inzetten van sleutelfiguren uit de wijk of gemeenschap en/of professionals met dezelfde (culturele) achtergrond lijkt ook een werkzaam element. Dit sluit ook aan bij de twee elementen van het thema competente en enthousiaste professionals. In de praktijk werkt het wanneer professionals eenzelfde achtergrond hebben als de doelgroep en respect tonen. Sleutelfiguren of bekenden begrijpen de doelgroep beter en geven ze een gevoel van veiligheid en vertrouwen. Een vertrouwensband helpt mensen met een kwetsbare positie om onderliggende problematiek te bespreken, en dat biedt ruimte om aan een gezonde leefstijl te werken, aldus de professionals. Ook deelnemers van de focusgroepen spraken een sterke voorkeur uit voor mensen met eenzelfde achtergrond.

Er was een professional die werkte bij [naam organisatie] en zij is zelf van Turkse afkomst en heeft meegewerkt aan de ontwikkeling van [naam interventie]. Ze heeft daarin de Turkse cultuur en hoe daarop aan te sluiten [...] een soort herken- ning voor de mensen en hun belangen. (Interview 1)

Het genoemde werkzame element bij continuïteit is dat programma's geborgd moeten worden. Professionals constateren dat veel programma's gefinancierd worden vanuit kortlopende subsidies. Na afloop moet de doelgroep weer wat nieuws zoeken, wat voor hen een drempel vormt.

Wat ik heel vaak terug hoor uit de gemeenschap is, ja er komen iedere keer dingen en na een jaar is het weer weg. Dus daar heb ik geen zin meer in. [...]. Ze worden een beetje moe [...] om met nieuwe dingen mee te doen, dus de borging is wel een heel belangrijke. (Interview 9)

\section{Gemeentelijk niveau}

Een potentieel werkzaam element op gemeentelijk niveau is dat professionals kennis van de sociale kaart hebben en zowel publieke als private organisaties betrekken bij het realiseren en financieren van onderdelen binnen de integrale aanpak. De reden is dat de doelgroep vaker te maken heeft met meerdere problemen. Wel is een voorwaarde dat de verschillende betrokkenen met elkaar samenwerken.

Kijk, als je bij ons kijkt, wij hebben fysiotherapeuten, leefstijlcoaches, diëtisten en trainers onder één dak. Dat is gewoon ons centrum en hiertegenover hebben we de huisarts. Dat is wel een voordeel. [...] Met inkomsten en zo, dan schakelen we de wijkteams in. Andersom zou het ook mooi zijn als zij mensen direct naar het beweegcentrum sturen. Vaak worden ze naar de huisarts gestuurd, gok ik. [...]. Ze komen dan alsnog bij ons. Maar het zou ook direct... het zou makkelijker kunnen. (Interview 11) 


\section{Landelijk niveau}

Professionals, zowel in de interviews als in de expertmeeting, benadrukten dat de landelijke overheid de verantwoordelijkheid heeft om te faciliteren. Voor deze doelgroepen is een gezonde leefstijl immers lastig te realiseren omdat gezonde producten vaak duur zijn, terwijl ongezonde producten relatief goedkoop zijn. Een potentieel werkzaam element is daarom het ter beschikking stellen van financiële middelen, zoals een vast bedrag per maand waarmee degenen die het nodig hebben zich een gezonde leefstijl kunnen veroorloven.

Als je denkt dat overgewicht een bijproduct is van lage SES, [...] dan zou je ook kunnen veronderstellen dat het als sneeuw voor de zon zou kunnen verdwijnen. [...]. Dan is dat gewoon een basisinkomen voor iedereen. (Interview 3)

\section{Sociale en fysieke omgeving}

Voor de doelgroep kan extra begeleiding vanuit de sociale omgeving, zoals een professional of iemand uit het eigen netwerk, nodig zijn om te werken aan een gezonde leefstijl. Volgens professionals kan dit bijvoorbeeld een casemanager zijn. Casemanagers zijn professionals die lokaal worden ingezet om mensen bij verschillende dagelijkse vaardigheden te begeleiden, zoals gezonde leefstijl of budgetplanning. De vertrouwensband tussen het individu en de casemanager zou hierin het werkzame element zijn.

Ik denk zelf dat het goed zou zijn als er één persoon naast een patiënt of deelnemer is. [...]. Dat diegene kan begeleiden in het zorgveld of het sociale veld waarin iemand met overgewicht zich begeeft. Dat er een vertrouwensband is en dat diegene ook begrijpt van deze situatie en dat diegene misschien zelf wel dingen kan oplossen. (Interview 8)

Er zijn geen specifieke werkzame elementen voor mensen met een lage SES en/of niet-westerse migratieachtergrond in de fysieke omgeving benoemd. Wel is bijvoorbeeld aangegeven dat activiteiten voor deze doelgroep in de buurt of op een bekende locatie moeten plaatsvinden. Dit zegt weliswaar iets over de inrichting van de leefomgeving, maar hebben we nu geplaatst onder het programmaniveau.

\section{Beschouwing en conclusie}

Het doel van dit exploratieve kwalitatieve onderzoek was om vanuit het perspectief van professionals en de doelgroep potentiële werkzame elementen te identificeren van een integrale aanpak van overgewicht bij mensen met een lage SES en/of een niet-westerse migratieachtergrond. Er zijn 41 potentieel werkzame elementen geïdentificeerd op het individuele, programma-, gemeentelijke en landelijke niveau, en de so- ciale en fysieke omgeving. Daarvan zijn 18 elementen benoemd als specifiek relevant voor mensen met een lage SES en/of een niet-westerse migratieachtergrond. Verder zijn vier competenties van professionals in kaart gebracht die nodig zijn om een integrale aanpak vorm te kunnen geven: verbinden, durven, integraal werken, volhouden. Daarnaast lijken tijd en geld belangrijke randvoorwaarden op alle niveaus te zijn.

In lijn met eerdere onderzoeken kwamen de potentiële werkzame elementen voor integrale aanpakken uit dit onderzoek op het individuele en programmaniveau het meest nadrukkelijk naar voren [15-17, 25]. In een scoping review over werkzame elementen van aanpakken bij kwetsbare doelgroepen zijn overeenkomstige werkzame elementen gevonden, zoals 'het inspelen op de wensen en behoeften van de specifieke doelgroep', 'het werven van de doelgroep door de inzet van sleutelfiguren' en 'materialen die aansluiten bij de geletterdheid en cultuur van de doelgroep' [17]. Dat vanuit de literatuur vooral werkzame elementen op het individuele en programmaniveau naar voren komen, is te verklaren doordat meestal gerapporteerd wordt over interventies.

Naast werkzame elementen op individueel en programmaniveau zijn in ons onderzoek ook op het landelijke, gemeentelijke, sociale en fysieke niveau werkzame elementen in kaart gebracht. Het belang van veranderingen in de bredere omgeving wordt onderstreept door Bagnall en collega's [25]. Zij noemen onder andere het betrekken van de gemeenschap, goed leiderschap, geschikte samenwerkingsverbanden en inbedding in de bredere context essentieel. Beauchamp en collega's concluderen dat bredere aanpakken gericht op structurele veranderingen in de omgeving (zoals toegang tot beweegactiviteiten in de buurt) of veranderingen in beleid (zoals gezond voedingsbeleid op scholen) effectiever zijn, dan interventies gericht op kennisverbetering en gedragsverandering bij mensen met een lage SES [11]. Ook de Raad voor Volksgezondheid en Samenleving stelt dat beleid gericht op de samenleving nodig is: 'It takes a society to fight complex inequality' [26]. Golden en collega's concluderen dat professionals het belang van beleids- en omgevingsveranderingen beter onder de aandacht moeten brengen om gezondheid te kunnen bevorderen [27].

Investeren in goede relaties, vertrouwen en de betrokkenheid van alle relevante partners vormen een sleutel tot een succesvolle integrale aanpak. Maar ook een gedeelde visie en waarden, en de manier waarop gemeenten worden bestuurd leiden tot een betere participatie, beleidsvorming en intersectorale activiteiten [25]. Deze bevindingen sluiten aan op de potentieel werkzame elementen op de verschillende niveaus en competenties die we in ons onderzoek gevonden hebben.

De meerwaarde van ons onderzoek is dat er gekeken is naar de potentieel werkzame elementen van 
een aanpak specifiek voor mensen met een lage SES en/of een niet-westerse migratieachtergrond. Daarnaast lag de focus op een bredere integrale aanpak in plaats van op een GLI gericht op gedragsverandering. In dit onderzoek zijn innovatieve en interdisciplinaire kwalitatieve methoden toegepast. Dit heeft geleid tot vruchtbare en prettige gesprekken, zowel met de professionals als de doelgroep. De tekeningen, waarin de integrale aanpak werd gevisualiseerd, stimuleerden de professionals om te brainstormen over elementen en randvoorwaarden, en hebben die aspecten belicht die met andere (kwantitatieve) methodieken lastig bloot te leggen zijn [20,21]. De perspectieven van professionals uit zowel beleid, praktijk als wetenschap tijdens (groeps)interviews, en de expertmeeting en de input van de eindgebruikers hebben een compleet overzicht van potentieel werkzame elementen en randvoorwaarden mogelijk gemaakt.

Een kanttekening bij het onderzoek is dat het voor de doelgroep die aan een leefstijlprogramma deelnam niet goed mogelijk was om inzicht te krijgen in de werkzame elementen voor een bredere integrale aanpak. Ze hebben daarom vooral potentieel werkzame elementen op het individuele en programmaniveau benoemd. Een andere kanttekening is dat het bij het categoriseren van de werkzame elementen soms lastig te boordelen was binnen welk niveau een element valt. Een vertrouwenspersoon, nu ingedeeld bij de sociale omgeving, kan bijvoorbeeld ook onderdeel uitmaken van het gemeentelijk niveau, wanneer de organisatie daarvan in handen van de gemeente is (bijvoorbeeld door het aanstellen van een casemanager). Ook zijn elementen niet altijd goed van elkaar te onderscheiden en beïnvloeden deze elkaar. Bijvoorbeeld de werkzame elementen behorend bij de thema's 'aandacht voor de sociale context' en 'aansluiten bij het dagelijks leven van de doelgroep'. Tot slot was het onderzoek exploratief van aard, waardoor we alleen potentieel werkzame elementen hebben kunnen achterhalen. Vervolgonderzoek kan zich richten op het toetsen van de werkzaamheid van de gevonden potentieel werkzame elementen en de werkzaamheid van combinaties van elementen. Bijvoorbeeld aan de hand van een realistische evaluatie waarin combinaties van mechanismen en contextuele factoren die leiden tot de gewenste uitkomsten worden geïdentificeerd [28].

De verworven kennis kan bijdragen aan de samenstelling van de meest optimale aanpak en kan professionals handvatten bieden om de werkzame elementen toe te passen in een integrale aanpak voor mensen met een lage SES en/of niet-westerse migratieachtergrond.

Open Access This article is licensed under a Creative Commons Attribution 4.0 International License, which permits use, sharing, adaptation, distribution and reproduction in any medium or format, as long as you give appropriate credit to the original author(s) and the source, provide a link to the Creative Commons licence, and indicate if changes were made. The images or other third party material in this article are included in the article's Creative Commons licence, unless indicated otherwise in a credit line to the material. If material is not included in the article's Creative Commons licence and your intended use is not permitted by statutory regulation or exceeds the permitted use, you will need to obtain permission directly from the copyright holder. To view a copy of this licence, visit http://creativecommons.org/licenses/by/4.0/.

\section{Literatuur}

1. Rijksinstituut voor Volksgezondheid en Milieu. Overgewicht volwassenen. 2021. https://www.volksgezond heidenzorg.info/onderwerp/overgewicht/cijfers-context/ huidige-situatie. Geraadpleegd op: 3 aug 2020.

2. Hilderink H, Verschuuren M. Volksgezondheid Toekomst Verkenning: een gezond vooruitzicht. Synthese. Bilthoven: Rijksinstituut voor Volksgezondheid en Milieu; 2018.

3. Rijksinstituut voor Volksgezondheid en Milieu. Gezondheidsverschillen. Hoe ontwikkelen zich gezondheidsverschillen in de toekomst? 2018. https://www.vtv2018.nl/ gezondheidsverschillen. Geraadpleegd op: 3 aug 2020.

4. Mulderij L, Verkooijen K, Wagemakers A. Gecombineerde Leefstijlinterventies voor mensen met een lage SES? Tijdschr Gezondheidswet. 2019;97:9-10.

5. Ministerie VWS van, Preventieakkoord N. Naar een gezonder Nederland. Den Haag: Ministerie van VWS; 2018.

6. Rinsum C van, Gerards S, Rutten G, et al. The coaching on lifestyle (CooL) intervention for overweight and obesity: a longitudinal study into participants' lifestyle changes. Int JEnviron Res Public Health. 2018;15:1-27.

7. Meer FM van der, Ligtenberg G, Staal PA, et al. Preventie bij overgewicht en obesitas: de gecombineerde leefstijlinterventie. Den Haag: Ministerie van Volksgezondheid, Welzijn en Sport; 2009.

8. Rijksinstituut voor Volksgezondheid en Milieu. Loketgezondleven.nl. Leefstijlinterventies. 2021. https://www. loketgezondleven.nl/leefstijlinterventies. Geraadpleegd op: 3 aug 2020.

9. Leenaars K, Viet L, Dale D van. Overzicht interventies in database loketgezondleven.nl. 2018. https://docplayer. nl/106821829-Overzicht-interventies-in-database-loket gezondleven-nl-karlijn-leenaars-lucie-viet-en-djoekevan-dale-november-2018.html. Geraadpleegd op: 3 aug 2020.

10. RIVM. Effecten van preventieve interventies: zijn er verschillen tussen mensen met een lage en een hoge sociaaleconomische status? Bilthoven: Rijksinstituut voor Volksgezondheid en Milieu; 2012.

11. Beauchamp A, Backholer K, Magliano D, et al. The effect of obesity prevention interventions according to socioeconomic position: a systematic review. Obes Rev. 2014;15(7):541-54.

12. Dale D van, Lanting L, Delden J van. Werkzame elementen, is dat de toekomst? Tijdschr Gezondheidswet. 2015;93(6):199-201.

13. Preller L, Schaars D. Generieke werkzame elementen van gecombineerde leefstijlinterventies en duurzame uitvoerbaarheid. Ede: Kenniscentrum Sport; 2016.

14. Bos V, Dale D van, Leenaars K. Werkzame elementen van gecombineerde leefstijlinterventies. Bilthoven: RIVM; 2019.

15. Mulderij L, Wolters F, Verkooijen KT, et al. Effective elements of care-physical activity initiatives for people with a low socio-economic status: a concept mapping study with health promotion experts. Eval Program Planning. 2020;80:1-11. 
16. Mulderij LS, Verkooijen KT, Koelen MA, et al. De werkzame elementen van een gecombineerdeleefstijlinterventievoor mensen met een lage sociaaleconomische status. Een concept mapping-caseonderzoek. Tijdschr Gezondheidswet. 2019;97(7):139-52.

17. Verbaan C, Rinsum C van, Dellas V, et al. Core elements of integral approaches for overweight and obesity amongst people with a low socioeconomic status or migrants: a scoping review. Wageningen: Wageningen University and Research;2019.

18. Merriam SB, Tisdell EJ. Qualitative research: a guide to design and implementation. New Jersey: John Wiley \& Sons; 2015.

19. Whitney D, Cooperrider DL. The appreciative inquiry summit: an emerging methodology for whole system positive change. OD Practitioner. 2000;32(1):13-26.

20. Checkland P, Poulter J.Learning for action: a short definitive account of soft systems methodology and its use for practitioners, teachers, and students. New Jersey: John Wiley \& Sons; 2006.

21. Zweifela C, Wezemaela J van. Drawing as a qualitative research tool. An approach to field work from a social complexity perspective. Tracey Journal: Drawing Knowledge. 2012;5:1-16.

22. Herens M, Wagemakers A. Assessing participants' perceptions on group-based principles for action in community- based health enhancing physical activity programmes: the APEF tool. Eval Program Planning. 2017;65:54-68.

23. Herens M, Wagemakers A, Vaandrager L, Koelen MA. Exploring participant appreciation of group-based principles for action in community-based physical activity programs for socially vulnerable groups in the Netherlands. BMC Public Health. 2015;15(1173):1-15.

24. Wagemakers A, Mulderij LS, Verkooijen KT, et al. Carephysical activity initiatives in the neighbourhood: study protocol for a mixed methods research on participation, effective elements, impact and funding methods. BMC Public Health. 2018;18(812):1-14.

25. Bagnall AM, Radley D, Jones R, et al. Whole systems approaches to obesity and other complex public health challenges: a systematic review. BMC Public Health. 2019;19(1):1-14.

26. Raad voor Volksgezondheid en Samenleving. Gezondheidsverschillen voorbij. Complexe ongelijkheid als een zaakvan ons allemaal. Den Haag: RVS; 2020.

27. Golden SD, McLeroy KR, Green LW, et al. Upending the social ecological model to guide health promotion efforts toward policy and environmental change. Health Educ Behav. 2015;42(7440):8-14.

28. Herens M, Wagemakers A, Vaandrager L, et al. Contexts, mechanisms, and outcomes that matter in Dutch community-based physical activity programs targeting socially vulnerable groups. Eval Health Prof. 2017;40(3):294-331. 